\title{
Access technology in academic libraries
}

\author{
By Mary Jo Lynch
}

\section{Most libraries offer access to remote databases and $C D-R O M$}

$n$ the last 20 years, four technologies have changed dramatically the way users gain access to bibliographic information. First came online searching of databases stored on computers in distant places. Initially this was done primarily through librarians, but gradually enduser searching became popular. Next came the online public access catalogs (OPACs) for searching the library's holdings. Then came the opportunity to search commercial databases owned or leased by the library in the shape of CD-ROMs. Most recently, those databases are available through the catalog in the form of locally mounted tapes.

The literature gives abundant evidence of the widespread use of these four technologies. Whole journals are devoted to some of them and articles appear frequently in general periodicals. Whole conferences are devoted to one or more of them and many meetings at general conferences. But does every academic library offer all of these services? How does their availability vary by type of academic institution?

Those questions were answered as a byproduct of the recent study on Alternative Sources of Revenue in Academic Libraries summarized in the October 91 issue of CERL News. For that study a four-page questionnaire was mailed to a sample of over 800 academic libraries stratified by the four basic categories in A Classification of Institutions of Higher Education published in 1987 by the Carnegie Foundation for the Advancement of Teaching: twoyear institutions, liberal arts colleges, comprehensive colleges and universities, and doctorate-granting institutions. Respondents were asked to describe their revenues in the most recent fiscal year, from five possible "alternative" sources of revenue: services, sales, and special events; computerized catalogs and databases, searching and printing; fines and replacement charges; gifts and grants; and library endowments. This article is based on answers to the section of the questionnaire on computerized catalogs and databases. Before asking if revenue was derived from those sources, the form first asked if four specified services were offered. Answers are shown here in figure 1 (figure 3 in the report) which shows, by Carnegie category, the percentage of respondents offering each type of service.

\section{Not a revenue source}

Most libraries do not charge for these services except for searching of remote databases - and this is not a major source of revenue. Tables in the full report show that a good number of libraries that charge do not actually receive the funds. The tables also show that students receive some or all searches free in many libraries. The report notes that many respondents added comments to the questionnaire about financing of remote database searching and warns that "we are not entirely confident in our data about revenue from this service." The author is confident, however, about the information shown in figure 1. The only caveat to be noted here is that the data were gathered in April 1990.

\section{What of the future?}

Evidence from the literature indicates that if the study were repeated in April 1992 the percentage of libraries offering these services would be higher, especially for CD-ROM and locally mounted tapes. The Office for Research 
Figure 1

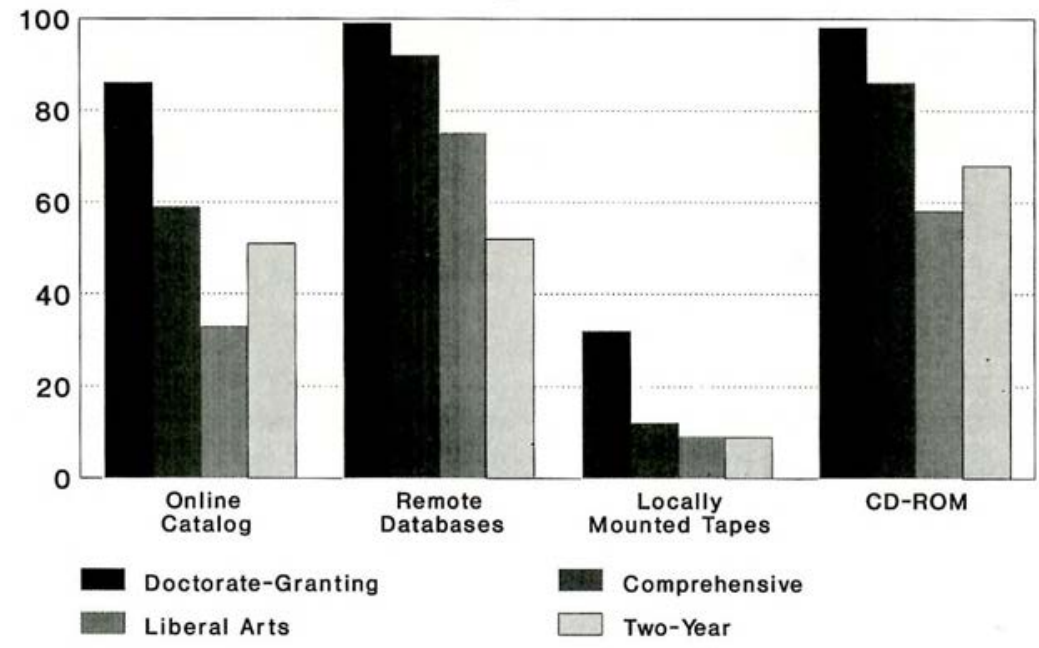

\section{Figure 1. Percentage of respondents offering searching of computerized catalogs and databases, by type of source.}

and Statistics (ORS) and ACRL hope to gather data on access technologies again in a few years. Will we want to ask about the same four technologies? Or will other access technologies be much more important then?

\section{(Rader cont. from page 242)}

for work experience and job exchange abroad. Likewise other library associations are establishing international committees and taskforces to address library-related international concerns. But much more work is needed on a broader scale to develop international library cooperation and information sharing, and ALA must assume a leadership role in this area.

American librarians need to support international library activities in terms of global information technologies. They must become leaders in building the global library community and share their library expertise with library communities in underdeveloped countries and newly emerging democracies. This becomes especially important at a time when many U.S. citizens see more of an isolationist role for the U.S. in world affairs.

It is noteworthy that U.S. librarians' interest in international activities continues to grow, especially since Eastern Europe has changed so dramatically. Our international colleagues
Ed. Note: Alternative Sources of Revenue in Academic Libraries is available for $\$ 10$ from: Order Department, American Library Association, 50 E. Huron St., Chicago, IL 60611; (800) 545-2433. ISBN: 0-8389-5742-0.

are hoping that we will share our experience, expertise, and resources with them to guide them in the development of their own library and information services. To help bring this about, we must work toward increasing the number of libraries and institutions which will actively support exchanges with foreign librarians or offer internships and practica. We must also internationalize the curricula in the library schools across the country to provide future librarians with the understanding of and skills to deal with international library and information concerns.

Through new electronic information and communication technologies the world is becoming a global information village, and libraries must be a vital part of that development. Librarians must be deeply and meaningfully involved in helping to shape the global information/scholarly community of the future. Only through involvement in international library and information activities can we ensure this will happen. 
Carlson Publishing is Pleased to Announce an Essential Reference Tool for Black Studies
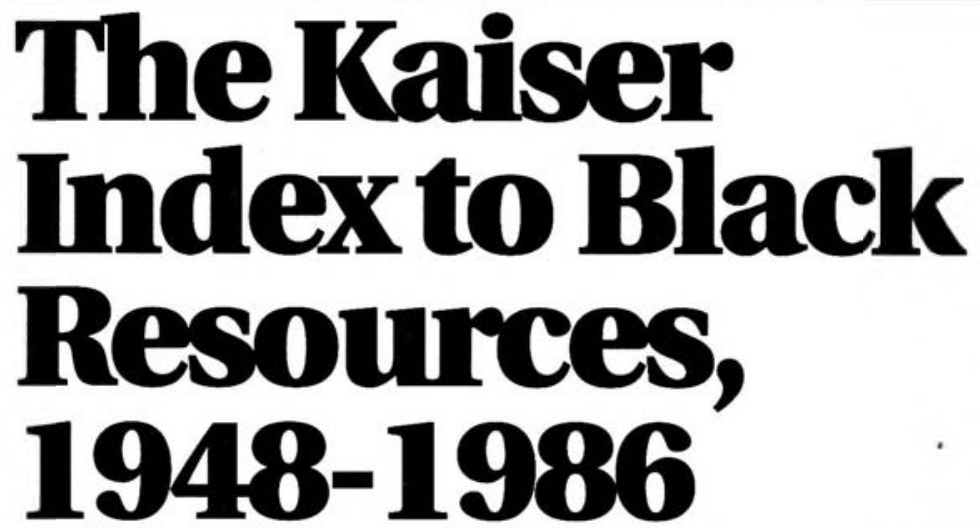

from the Schomburg Center for Research in Black Culture of the New York Public Library

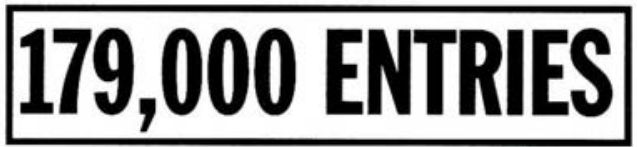

"Having used the Kaiser Index for 21 years, I can say the information there is often the only citation the reader can find. The wide coverage, in time and sources, makes the Index a reference tool no researcher in black studies can afford to be without."

Betty Kaplan Gubert

Head, General Research and Reference, The Schomburg Center, Fetired

This monumental reference resource provides unparalleled access to the lives of African-Americans. Most of the journals, magazines, and newspapers cited are indexed in no other source. For a free descriptive brochure, call our toll-free line or drop us a note:

Carlson Publishing, Inc.; P.O. Box 023350;

Brooklyn, New York 11202-0067

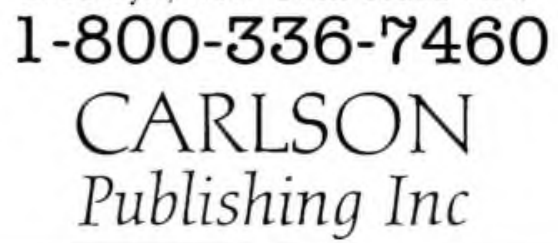

